\title{
PENYEBAB KONFLIK RUMAH TANGGA PADA KLIEN SATRIA UTAMA RELATIONSHIP COACH
}

\author{
Muhammad Faiz Hasyfi Prayogo \\ Universitas Brawijaya, Malang, Indonesia. \\ faiz.hasyfi@gmail.com
}

\begin{abstract}
Research in communication especially in marital conflict later are developed because of practical needs in improving family relations quality. This research aims to know causes of conflict in the family by a relationship coach. This research is using phenomenological method to obtain in-depth data from informant who experience in providing consultancy in domestic life named Satria Utama whom establish a relationship coach for seven years. Collecting data methods that is used for this research is in-depth interview and it's analyzed with phenomenological research steps. There are three factor that causing marital conflict: genderlect styles, encoding-decoding process in communicate feelings, and family communication pattern. This analysis conclude that the three factor is a unity and cannot be separated. The communication differentiation between man and woman that occur is not about dialectic, but man and woman speak with different genderlect. One way to improve marital communication quality is a safe feeling in expressing feelings. Many people cannot express their feelings clearly to their spouse, so they need a coach to describe their feelings verbally based on some situation. Parents also affect how their kids marital relationship later when they grow up. Conflicts that happen in marriage relationship cannot be separated from how their parents communication pattern with their kids when they were kids.
\end{abstract}

Keywords: gender, family, communication, conflict

\begin{abstract}
Abstrak
Banyak keluarga menghadapi perjuangan sulit yang seringkali tidak dapat diprediksi dan menimbulkan masalah dalam komunikasi. Penelitian komunikasi dalam konflik keluarga kemudian dikembangkan karena kebutuhan praktis dalam meningkatkan kualitas hubungan dalam keluarga. Penelitian ini bertujuan untuk mengetahui penyebab konflik dalam keluarga oleh relationship coach. Penelitian ini menggunakan metode fenomenologi untuk mendapatkan data yang mendalam dari seorang informan yang telah berpengalaman dalam memberikan konsultasi dalam kehidupan rumah tangga yaitu Satria Utama yang telah mendirikan relationship coach selama tujuh tahun. Teknik pengumpulan data yang dilakukan dalam penelitian ini adalah wawancara mendalam dan dianalisis dengan menggunakan tahap-tahap dalam penelitian fenomenologi. Hasil penelitian yaitu ada tiga faktor yang konflik rumah tangga yaitu: genderlect styles, proses encodingdecoding dalam mengkomunikasikan perasaan, dan pola komunikasi dalam keluarga yang terjadi secara kesatuan dan tidak dapat dipisahkan.Perbedaan cara berkomunikasi yang terjadi pada pria dan wanita itu bukanlah perbedaan dialek, namun pria dan wanita berbicara menggunakan perbedaan genderlect. Banyak orang tidak bisa menyampaikan perasaan kepada pasangannya, sehingga dibutuhkan coach dalam proses mendeskripsikan perasaan secara verbal terhadap suatu keadaan. Orang tua juga mempengaruhi bagaimana hubungan pernikahan anaknya kelak ketika dewasa. Konflik yang terjadi dalam rumah tangga tidak terlepas dari bagaimana pola komunikasi orang tua terhadap anak ketika masih kecil.
\end{abstract}

Kata kunci: gender, keluarga, komunikasi, konflik

\section{PENDAHULUAN}

Masyarakat saat ini menghadapi berbagai permasalahan dalam aspek rumah tangga. Hal ini terlihat dari banyaknya kasus perceraian hingga ketakutan generasi muda untuk melanjutkan hubungan romantisnya menuju ke jenjang pernikahan. Hal ini adalah permasalahan yang sudah ada sejak lama 
walaupun mungkin saat ini terjadi peningkatan pada permasalahn interaksi laki-laki dan perempuan. Permasalahan gender menjadi perhatian besar di masyarakat ataupun para ahli ilmu sosial. Cara berkomunikasi suami istri, persepsi, kemampuan mendengar dipengaruhi oleh budaya, dan gender. Pria dan wanita memiliki gaya berbeda dalam berkomunikasi karena mereka mempunyai gaya berbeda pula dalam menggunakan pesan verbal maupun non-verbal (De Vito, 2004).

Komunikasi pria dan wanita dalam aspek komunikasi lintas budaya, bisa dicontohkan seperti dua orang yang sedang berbicara dari dua negara yang berbeda. Banyak bahasa yang bertentangan/berlawanan dengan yang dimaksud dalam percakapan antara pria dan wanita. Sebagai contoh adalah ketika terjadi pertengkaran suami istri, dan wanita memilih untuk diam sebagai pesan bahwa dia (istri) menghukum suaminya, maka suaminya akan lebih menikmati suasana sepi yang diberikan pasangannya, yang pada akhirnya dia (suami) sadar bahwa diam yang dilakukan sang istri adalah awal mula dari sebuah konflik.

Perspektif yang berbeda tentang stereotipe memungkinkan wanita ketika memberikan perintah memang akan melakukannya secara tidak langsung, namun hal itu bukan menunjukkan kurangnya power,yaitu kemampuan untuk memilih gaya komunikasi sendiri. Pria juga melakukan komunikasi tidak langsung dalam situasi berbeda, seperti misalnya ketika mengekspresikan kekurangan, menunjukkan adanya masalah, atau mengakui adanya kesalahan. Pria akan mengekspresikan emosinya secara tidak langsung, kecuali kemarahan yang bisa langsung mereka ekspresikan. Pada intinya, pria akan melakukan komunikasi tidak langsung ketika mereka mengatakan sesuatu yang tidak sesuai dengan stereotip maskulin.

Stereotip tentang pria dan wanita berubah menyesuaikan perkembangan dari kedewasaan dari seseorang, dan seringkali negatif (Saguni, 2014). Masyarakat yang berperilaku sesuai gender terus mempengaruhi orang tersebut, bukan hanya ketika kecil, tapi seumur hidupnya. Berbagai permasalahan gender ini akhirnya menyebabkan konflik dalam keluarga.

Berkaitan dengan konflik keluarga, ada suatu perbedaan yang terjadi antara siapa yang memberi tekanan dalam konflik berbeda efek didalam hubungan, yaitu tekanan yang dilakukan oleh pria cenderung lebih mempengaruhi kepuasan di dalam keluarga dibanding sebaliknya (Velotti et al., 2016). Kemudian tekanan terhadap pasangan yang dilakukan secara berlebihan akan mengancam keutuhan dan keharmonisan close relationship (English, T., John, O. P., Srivastava \& Gross, 2012).

Interaksi didalam berkomunikasi orangtua dan anak mengandung pesan dan informasi yang selalu dipertukarkan. Antar anggota komunikasi biasanya menginformasikan langsungaktivitas masing-masing yang sudah dilakukan sepanjang hari (Rini, 2014). Hubungan antara anggota keluarga bisa dilihat dari dua dimensi dari pola komunikasi keluarga tersebut responden dikelompokkan menjadi empat jenis keluarga berdasarkan tinggi dan rendahnya respon mereka pada dua variabel tersebut (Ritchie \& Fitzpatric, 1990). Keluarga dari responden yang mempunyai nilai tinggi pada orientasi konsep tapi rendah pada orientasi sosial disebut pluralistic. Keluarga pluralistic menekankan hubungan antara anak-anak dan konsep atau isu. Keluarga dari responden yang memiliki orientasi konsep yang rendah dan orientasi sosial yang tinggi disebut protective. Keluarga protective menekankan hubungan ketaatan dan kepatuhan antara anak-anak dan orang tua. Keluarga dari responden yang memiliki nilai tinggi pada kedua dimensi disebut consensual. Keluarga consensual berusaha mengkombinasikan kepatuhan dan keterbukaan. Yang terakhir, keluarga dari responden yang memiliki nilai yang rendah pada dua dimensi disebut laissez-faire. Keluarga laissez-faire menunjukkan tidak adanya aturan komunikasi yang konsisten, mengakibatkan 
sangat sedikit komunikasi yang terjalin antara orang tua dan anak-anak.

Konflik di dalam interaksi bisa berupa verbal dan nonverbal (Wardyaningrum, 2013). Komunikasi verbal yang positif merupakan salah satu komponen dalam melakukan resolusi konflik yang konstruktif (Karel, Sondakh, \& Pasoreh, 2014). Menjadi sulit bagi pria untuk mengungkapkan perasaannya, karena memang seperti yang sudah disebutkan sebelumnya bahwa pria berkomunikasi lebih menggunakan komunikasi langsung dan cenderung bersifat verbal, dan kata-kata tidak cukup untuk menyampaikan emosi yang dirasakan. Sebuah kata-kata "kalau pergi tolong nanti kabarin ya" dari seorang istri dapat dimaknai sebagai salah satu cara untuk menjalin kedekatan menurut wanita, namun bisa jadi merupakan sebuah perintah dari wanita dan menyebabkan pria merasa mempunyai power dibawah wanita jika meminta izin. Aspek ini bisa mengantarkan pada data jumlah pernikahan dan presentase angka perceraian yang ada.

Angka pernikahan setiap tahun menurun, sedangkan presentase angka perceraian setiap tahun bertambah. Penyebab konflik ada duajenis stres yaitu stres dalam hubungan pernikahan yang bisa menyebabkan konflik, yaitu stres eksternal dan stres hubungan (Ledermann, G., Rudaz, \& Bradbury, 2010). Stres adalah respon yang kurang menyenangkan dari tubuh yaitu berupa tekanan akibat adanya interaksi individu dengan stresor yang menghasilkan perubahan biologis, psikologis, dan perilaku (Litiloly \& Swastiningsih, 2014).

Stres eksternal mengacu kepada ketegangan yang berasal dari luar hubungan, seperti masalah sosial dan ekonomi, masalah pekerjaan, konflik dengan tetangga, atau masalah dengan pemerintah. Sedangkan stres hubungan mengacu kepada ketegangan yang muncul dari dalam hubungan dalam bentuk kebutuhan dan perilaku berbeda-beda atau kebiasaan yang mengganggu dari salah satu partner. Kepuasan pernikahan lebih dipengaruhi oleh stres yang terjadi dari dalam hubungan daripada yang berasal dari luar hubungan(Bodenmann, G., Ledermann, \& Bradbury, 2007).

Faktor stres hubungan adalah faktor utama timbulnya konflik pernikahan(Ledermann et al., 2010). Stres hubungan mempunyai peran yang selaras dengan komunikasi pernikahan yang mempengaruhi kualitas pernikahan, dan menyarankan bahwa peningkatan dalam komunikasi pernikahan dan pengurangan stres hubungan yang dirasakan oleh pasangan bisa mencegah kerusakan dari harmoni pernikahan. Selain itu perasaan dimengerti juga merupakan salah satu cara untuk mengurangi dampak buruk dari konflik yang terjadi di rumah tangga (English \& John, 2013). Salah satu cara meningkatkan komunikasi pernikahan adalah perasaan aman dalam menyampaikan perasaan (Harper, 1958). Banyak orang tidak bisa menyampaikan perasaan secara tepat kepada pasangannya, sehingga dibutuhkan konselor dalam proses mendeskripsikan perasaan secara verbal terhadap suatu keadaan (Folsom, 1958). Konselor harus memberikan perasaan aman dan nyaman dalam sesi konselingnya supaya klien tidak merasa terancam ketika mengekspresikan perasaan sebenarnya. Penulis memilih Satria Utama Relationship Coach karena menggunakan metode tidak menghakimi melainkan lebih kepada membuka diri klien dengan membuka blind spot dari klien dan menemukan jawaban tentang tindakan apa yang harus diambil.

Satria Utama adalah relationship coach pertama di Indonesia dengan metode yang berbeda dengan relationship consultant. Secara bahasa, coach dan consultant mempunyai arti yang berbeda. Menurut Oxford Dictionary, consultant mempunyai makna seseorang yang menyediakan saran secara professional, sedangkan coach mempunyai makna pengajar atau orang yang memberikan pelatihan privat. Menurut Satria Utama, consultant akan memberikan saran dan tips sesuai dengan kasus yang dialami klien, sedangkan coach lebih kepada mendengarkan dan membantu klien untuk mengenal dirinya sendiri sehingga dapat 
menemukan sendiri jawaban atas kasus yang dialaminya. Dalam hal ini coach memerankan diri menjadi teman karena dengan pertemanan komunikasi yang efisien sangat mungkin untuk dibangun (James \& Mazer, 2012).

Kebaruan fenomena relationship coach di Indonesia mendorong peneliti untuk mengetahui lebih dalam bagaimana pola komunikasi dalam konflik rumah tangga pada klien Satria Utama ini dan penyebab konflik rumah tangga pada kliennya. Dengan memahami pola komunikasi dan penyebab konflik penelitian ini bertujuan untuk memahami fenomena baru tersebut dan mampu memberikan beberapa saran yang tepat dalam penyeleaian konflik pada rumah tangga keluarga pada mayasrakat Indonesia. Penelitian ini tentunya akan memberikan nilai tambah pada kajian Komunikasi Keluarga yang saat ini didominasi oleh penelitian tentang keluarga dan hubungannya dengan perkembangan teknologi, kemudian ada juga yang berkaitan dengan parenting. Contoh penelitian Komunikasi keluarga dan perkembangan teknologi adalah penelitian yang berjudul "Toward Traditional or Atypical Parenting: Mediated Communication in Chinese Transnational Families" (Chen, 2019). Sedangkan penelitian tentang keluarga dan politik salah satu contohnya adalah berjudul "Blood Is Thicker Than Water": Interpersonal Influence, Selection, and the Role of Family in Forging Italians' Political Agreement" yang dilakukan oleh (Oswell, 2006). Dari review terhadap penelitian yang dilakukan oleh peneliti kajian yang mendalami tentang konflik keluarga dan coach masih belum ada sehingga penelitian ini diharapkan menjadi masukan berharga terhadap kajian tentang Komunikasi keluarga.

\section{METODOLOGI}

Paradigma penelitian yang dipakai dalam penelitian ini menggunakan paradigma konstruktifis. Memiliki sifat purposefull sampling,menghimpun open-ended data, analisis dari teks atau gambar yang menginterpretasikan informasi pada suatu bentuk, table-tabel dan interpretasi personal. (Creswell, 2014). Sedangkan metode dari penelitian ini menggunakan Fenomenologi. Menurut Schutz, objek penelitian ilmu sosial pada dasarnya berhubungan dengan interpretasi terhadap realitas (Kuswarno, 2009). Pendekatan kualitatif dengan metode fenomenologi ini tidak hanya menjelaskan tentang berbagai tindakan individu secara apa adanya yang terlihat, namun juga harus secara rinci, kontekstual, dan menyeluruh. Yang pada hasilnya nanti, hasil penelitian bukan hanya deskripsi rinci, namun juga bisa menjelaskan makna dibalik tindakan individu subjek penelitian, atau yang bisa disebut noumena (Fatchan, 2013).

Teknik pengumpulan data dilakukan peneliti dengan wawancara langsung kepada Satria Utama sebagai Coach supaya bisa menjelaskan secara mendalam tentang konflik yang terjadi dan apa penyebabnya. Penelitian yang hanya menggunakan satu informan ini menggunakan teknik triangulasi data yang dikemukakan informan. Sehingga peneliti melakukan validasi atau memberikan pertanyaan yang berbeda dengan poin yang sama untuk mengklarifikasi konsistensi informan dalam memberikan setiap datanya. Setiap nama yang muncul dari data informan selain Satria Utama adalah klien dari relationship coach ini. Peneliti tidak langsung melakukan wawancara ke para klien ini, tetapi peneliti mendapatkan setiap data tentang klien tersebut dari informan.

\section{HASIL DAN PEMBAHASAN}

Seorang klien Lia mulai berkonsultasi (coaching) dengan Satria Utama ketika sedang dalam proses perceraian dengan suaminya namun sudah dekat dengan pria lain. Suami Lia berselingkuh dengan wanita lain yang ternyata teman kantor Lia. Padahal Lia sangat percaya dengan suaminya, malah suaminya yang overprotektif terhadap Lia. Lia tidak bisa memaafkan suaminya meskipun telah meminta maaf dan tetap menginginkan perceraian. Proses perceraian berlangsung sangat lama karena Lia juga masih memikirkan anak- 
anaknya dan karir suaminya yang waktu itu juga sedang jatuh. Segera setelah keadaan membaik, proses perceraian dilanjutkan meskipun masih terhambat karena persoalan hak asuh anak yang rumit, namun pada akhirnya hak asuh anak dimiliki oleh Lia. Lia sulit sekali memaafkan suaminya karena orang tuanya sudah sering berpesan untuk jangan pernah memaafkan orang yang berselingkuh.

Lia mulai coaching kepada Satria Utama ketika dekat dengan seorang pria namun masih ragu karena masih dalam proses perceraian dan dan masih ada perasaan tidak percaya kepada pria karena sudah dikecewakan dengan suaminya sebelumnya. Dia tertarik dengan pria yang berumur lebih muda namun menurutnya menarik karena banyak bicara, seru, dan sangat komunikatif. Tidak lama menjalin hubungan dengan pria ini, ternyata dari sosial media ketahuan bahwa pria ini selingkuh juga, kemudian dia kembali terpuruk dan melanjutkan coaching dengan Satria untuk bisa memulihkan perasaannya dan kembali bimbang dengan perasaannya antara ingin menikah lagi atau tidak.

Dalam proses coaching diketahui bahwa Lia tidak memiliki kriteria khusus untuk calon pasangannya nanti, sehingga efeknya adalah seringkali dia bertemu dengan pria yang hanya ingin pacaran namun belum mau menikah. Kemudian Lia memutuskan untuk fokus mencari suami lagi dan akhirnya berkenalan dengan seorang pria lagi. Pria itu dikenalkan oleh tetangganya, dan tidak lama kemudian menjadi suaminya. Setelah menikah, ada perubahan cara berkomunikasi dari suaminya. Suaminya menjadi lebih pasif, padahal Lia mempunyai karakter yang cerewet dan lebih dominan. Banyak kebiasaan yang berubah ketika sudah menikah. Suaminya jarang meminta izin untuk pergi kemanamana. Lia dan suaminya mempunyai jam tidur yang berbeda, Lia biasa tidur malam dan bangun siang, sedangkan suaminya sebaliknya, biasa tidur cepat dan bangun pagi. Karena Lia terbiasa berbicara menggunakan intonasi tinggi, suaminya merasa terganggu dan tidak suka dengan kebiasaan Lia tersebut. Pernah terjadi kesalah pahaman ketika kepala Lia terbentur di kamar mandi dan berteriak, oleh suaminya dipikir marah, kemudian didiamkan lama oleh suaminya. Lia bertanya kepada suaminya mengapa aneh dan diam, setelah tahu alasannya, Lia menjelaskan bahwa Lia tidak marah, hanya sakit karena kepalanya terbentur. Masalah lain adalah suaminya selalu menunggu Lia ketika pulang kantor karena suaminya ini tidak dekat dengan anak-anak Lia. Karena terlalu pasif, suaminya tidak bisa membangun obrolan dengan anak-anak, bahkan ketika pergi bersama keluarga, suaminya juga tidak aktif melakukan komunikasi dengan anak maupun istrinya atau malah cenderung pasif.

Menurut Satria, suami Lia ini hanya ingin menikah dengan Lia namun tidak siap dengan konsekuensinya ketika menikah dengan janda yang memiliki dua anak. Banyak klien dari Satria yang ingin menikah namun belum siap menikah. Orang tua tidak pernah memberi pengetahuan tentang bagaimana cara menghadapi wanita ketika menjadi suami, ataupun cara menghadapi pria ketika menjadi istri. Orang tua hanya memberi batasan yang kurang jelas, seperti “jangan main sama cewek/ cowok". Rata-rata pria atau wanita mendapat gambaran tentang pernikahan justru dari luar keluarga, sangat sedikit yang mendapat pendidikan tentang pernikahan dari keluarga itu sendiri. Satria sendiri mendapat gambaran tentang pernikahan dari orang tua pada waktu SMP hanya dengan kata-kata "pernikahan itu gini, gak selamanya manis", namun orang tuanya hanya menjelaskan sebatas itu saja tanpa memberikan alasan yang tepat, seperti misal pertanyaan kenapa tidak boleh pacaran, kenapa takut hamil, kenapa bisa hamil, dll. Mereka tidak bisa menjelaskan karena memang tidak memiliki pengetahuan tentang pendidikan pernikahan juga. Orang tua kebanyakan hanya menjelaskan persiapan pernikahan dari segi materi, namun bukan dari segi mental. Orang tua tidak memberikan pemahaman tentang standar 
kemapanan, sehingga pria dan wanita memiliki standar kemapanan yang berbeda. Wanita di Indonesia memiliki pemahaman bahwa standar mapan adalah secara finansial, padahal seharusnya mapan haruslah secara emosi, pengetahuan, dan finansial. Rata-rata klien yang baru menikah tidak memiliki pengetahuan tentang kemapanan tersebut, padahal saat ini banyak seminar tentang pernikahan, namun mereka kebanyakan tidak tertarik karena menurut mereka menikah itu adalah hal yang mudah, yang penting sudah cinta. Mereka menganggap bahwa pernikahan sama dengan pacaran, sehingga tidak terlalu membutuhkan konseling atau pendidikan tentang pernikahan karena merasa sudah memahami pasangannya dalam proses pacaran tersebut.

Kebanyakan yang memiliki masalah komunikasi dalam suatu hubungan adalah pria. Ada klien Andi, seorang pria berumur 46 tahun belum menikah yang awalnya sering berkonsultasi ke pendeta tentang pernikahan. Andi merasa bahwa pacarnya adalah orang yang sangat suka menuntut, seperti misalnya meminta diberi kabar, ditelepon, dan lain sebagainya, padahal dia lebih suka biasa saja, tidak usah lah terlalu sering memberi kabar. Kemudian coaching dengan Satria, dan menurut Satria itu adalah hal yang wajar karena wanita memang ingin diberi kepastian.

Permasalahan terbesar klien pada pernikahan adalah cara berkomunikasi. Ketika seseorang tidak punya banyak uang namun bisa mengkomunikasikan dengan baik, harusnya konflik bisa mereda. Pria mempunyai kesulitan untuk merayu, padahal konflik sebesar apapun akan bisa diredam dengan rayuan dan sentuhan. Ada klien Yuli yang bertengkar hanya karena tidak disapa "good morning" oleh pacarnya. Dia berkata "gila Sat, masa gua gak di-good morning-in". Menurut Satria hal yang sangat sederhana seperti "good morning" itu sangat penting bagi wanita, dan wanita berharap bahwa perhatian yang diberikan pria itu harus konstan, meningkat boleh, namun tidak boleh berkurang.
Pria harus paham bahwa wanita itu lebih peka secara emosional daripada logika. Ketika wanita pulang dari kantor atau capek bekerja di rumah, mereka akan bercerita bukan untuk diberikan solusi secara logika, namun hanya ingin didengarkan. Pertengkaran rumah tangga sering terjadi ketika wanita diberi solusi ketika bercerita, padahal sebenarnya hanya ingin didengar saja.Lia mau membayar coach dengan biaya mahal hanya untuk mendengarkan ceritanya. Hal yang sama juga dilakukan klien Didi yang meninggalkan psikolog karena terlalu banyak diberi nasihat dan akhirnya beralih juga ke Satria.

Metode yang digunakan Satria adalah mendengarkan keluhan klien, kemudian mengikuti apa yang klien mau kemudian mengarahkan mereka supaya pada akhirnya mereka akan menemukan sendiri jawaban dari permasalahannya. Memang harus sabar dan pelan-pelan untuk mengikuti dan menggiring kembali ke koridor awal tujuan konsultasi.

Menurut Satria, wanita mempunyai intuisi yang lebih baik daripada pria, jadi tahu sebenarnya ketika pria berbohong, namun tetap saja kadang wanita mau mendengarkan. Misalnya ketika ada pria mengatakan "lu manis banget", wanita tetap akan menyukainya meskipun tahu itu hanya menghibur dan sebenarnya kondisinya saat itu tidak seperti itu. Romantis yang diharapkan wanita sebenarnya adalah sebuah kebohongan, wanita sebenarnya tahu bahwa pria hanya baik pada saat pendekatan saja, namun wanita berharap hal tersebut tetap terjadi pada saat berpacaran maupun menikah.

\section{Pembahasan}

\section{Genderlect styles}

Konflik yang pada klien Satria Utama salah satunya karena perbedaan cara berkomunikasi, seperti pada klien Lia yang suaminya jarang meminta izin jika ingin kemana-mana, pada klien Andi juga merasa dituntut oleh pasangannya untuk selalu memberi kabar 
dan meneleponnya, kemudian pada klien Yuli yang bertengkar karena tidak disapa "good morning" oleh pasangannya. Kedekatan adalah kunci dari dunia hubungan antar individu yang menegosiasikan tentang kerumitan pertemanan, mengurangi perbedaan, mencoba mencari kesepakatan, dan menghindari superioritas yang akan memperlihatkan perbedaan (Tannen, 1990). Dalam dunia yang membutuhkan status, kebebasan adalah kuncinya, karena makna sesungguhnya dari memunculkan status adalah memerintah orang lain untuk melakukan sesuatu, dan menerima perintah adalah tanda dari status yang rendah. Meskipun semua orang membutuhkan kedekatan dan kebebasan, tapi wanita lebih fokus kepada kedekatan dan sedangkan pria cenderung kepada kebebasan.

Perbedaan ini membuat pria dan wanita mempunyai perbedaan cara pandang terhadap situasi yang sama. Seperti misalnya masalah izin untuk melakukan sesuatu, banyak wanita yang menganggap konsultasi dengan pasangan setiap saat adalah hal yang sangat natural dan wajar, sementara banyak pria secara otomatis membuat banyak keputusan tanpa berkonsultasi dengan pasangan. Hal ini merefleksikan perbedaan yang sangat mendasar dalam proses pembuatan keputusan. Wanita mengharapkan keputusan dapat didiskusikan dulu dan kemudian baru diputuskan ketika sudah mencapai kesepakatan bersama. Wanita menghargai proses diskusi itu sendiri sebagai bentuk keikutsertaan dalam membuat keputusan dan komunikasi. Sedangkan pria banyak yang merasa tertekan dengan diskusi yang panjang tentang sebuah keputusan kecil menurut pria. Pria juga merasa tertekan jika mereka tidak bisa bertindak tanpa berbicara terlebih dahulu. Ketika wanita mencoba memulai diskusi dengan pertanyaan "bagaimana menurutmu?", pria sering berpikir bahwa mereka sedang diperintah untuk memutuskan sesuatu.

Menurut Satria Permasalahan terbesar klien pada pernikahan adalah cara berkomunikasi. Ketika seseorang tidak punya banyak uang namun bisa mengkomunikasikan dengan baik, harusnya konflik bisa mereda. Pria mempunyai kesulitan untuk merayu, padahal konflik sebesar apapun akan bisa diredam dengan rayuan dan sentuhan. Wanita menginginkan kedekatan dan pria menginginkan status adalah karena dia mendengarkan pria dan wanita ketika berbicara (Tannen, 1990). Rapporttalk adalah tipe pembicaraan yang dilakukan wanita yang bertujuan untuk membangun hubungan dengan orang lain, sedangkan reporttalk adalah tipe pembicaraan monolog pria yang bertujuan untuk memberikan perintah, menyampaikan informasi, dan memenangkan argumen. Tannen meneliti dengan cermat sampel yang mewakili budaya feminim dan budaya maskulin untuk menentukan nilai inti masing-masing budaya. Dapat dibuktikan dari mengapa wanita suka dirayu, karena sebenarnya wanita menyukai percakapan-percakapan kecil untuk membangun kedekatan. Bahkan hal-hal seperti menelepon, memberi kabar adalah tipe pembicaraan yang sangat disukai wanita dan seringkali diabaikan oleh pria yang mempunyai tipe pembicaraan monolog, memberikan saran, dan memenangkan argumen.

\section{Proses encoding-decoding komunikasi perasaan}

Setelah menikah, ada perubahan dari perilaku suami Lia, yaitu menjadi lebih pasif. Ada ketakutan untuk berkomunikasi dengan anak-anak Lia dan juga tidak bisa memahami apa yang keinginan Lia, terbukti saat ada konflik karena Lia terbentur di kamar mandi, suami Lia mendiamkan Lia karena merasa marah karena Lia berkata kasar dan dengan nada tinggi, padahal itu adalah hal yang biasa. Pesan yang sebenarnya disampaikan Lia adalah kesakitan karena terbentur, namun metamessage yang sampai ke suaminya adalah Lia marah dan berkata kasar. Hal ini terjadi karena gaya komunikasi yang berupa gaya bicara, intonasi, nada, suara, dan gesture mempengaruhi efektifitas komunikasi (Daryanto, 2010). Melihat hal tersebut, efektifitas komunikasi merupakan hasil dari kompetensi komunikasi 
(Morreale, 2011).

Pasangan dengan tingkat penyesuaian diri yang tinggi mempunyai tingkat akurasi encoding-decoding yang tinggi dibandingkan pasangan yang dengan tingkat penyesuaian diri yang rendah, alasan utamanya adalah karena suami dengan tingkat penyesuaian diri yang rendah mempunyai nasib yang buruk dalam menjadi encoder maupun decoder. Sebagai encoder, suami mempunyai sedikit pesan yang dianggap sebagai komunikasi yang bagus, sedangkan sebagai decoder, mereka mempunyai interpretasi yang tidak akurat terhadap pesan istri, meskipun ketika pesan tersebut sudah dianggap sangat jelas maksudnya. Hal ini mengarah kepada terhambatnya alur proses sosial dan interaksi sosial yang disebabkan terjadinya masalah pada proses encoding serta decoding (Suroyya, Wisadirana, \& Suryadi, 2014) .Ketika wanita pulang dari kantor atau capek bekerja di rumah, mereka akan bercerita bukan untuk diberikan solusi secara logika, namun hanya ingin didengarkan. Pertengkaran rumah tangga sering terjadi ketika wanita diberi solusi ketika bercerita, padahal sebenarnya hanya ingin didengar saja. Hal ini juga salah satu bentuk kegagalan metacommunicate pasangan, bahwa mereka sebenarnya hanya ingin ditenangkan secara emosional, bukan diberi solusi masalah secara logis.

\section{Pola komunikasi keluarga}

Lia tidak bisa memaafkan suaminya karena pengaruh orang tuanya yang selalu menekankan untuk tidak memaafkan pria yang berselingkuh. Orang tua memang mempengaruhi bagaimana hubungan pernikahan anaknya kelak ketika dewasa. Hal ini karena disebabkan karena anak muda yang hidup dengan orang tuanya akan terpengaruh oleh aturan dari orang tuanya. Aturan ini dikuatkan dengan pola aktifitas keluarga dan pemerintah (Shun \& Wilkinson, 2020). Dikuatkan lagi dengan pandangan bahwa individu yang secara psikologis bergantung pada orang tua akan menghadapi tantangan lebih dalam membangun hubungan dekat dengan orang lain (Cook \& Fletcher, 2012). Konflik yang terjadi dalam rumah tangga tidak terlepas dari bagaimana pola komunikasi orang tua terhadap anak ketika masih kecil. Hubungan orang tua-anak yang buruk yang menyebabkan stres pada masa kecil bisa mempengaruhi kehidupan anak tersebut ketika dewasa. Orang yang mempunyai stres pada masa kecil akan lebih reaktif pada stres ketika dewasa dan kualitas pernikahan akan lebih cepat menurun ketika merespon stres yang terjadi ketika dewasa (Reckzek, Liu, \& Umberson, 2010). Hal ini sesuai dengan studi terbaru tentang pola parenting dan hubungan antara orang tua dan anak mempengaruhi kesehatan psikologis dan hubungan interpersonal seseorang (Odenweller, K., Booth-Butterfield, M., \& Weber, 2014). Seperti yang dikatakan Satria sebelumnya bahwa banyak klien dari Satria yang ingin menikah namun belum siap menikah. Walaupun di awal menikah biasanya pasangan akan mengidealkan satu sama lain, tetapi lama kelamaan hal itu akan berkurang bahkan mempersepsikan pasangannya secara negatif (Hall \& Adams, 2011).

Orang tua tidak pernah memberi pengetahuan tentang bagaimana cara menghadapi wanita ketika menjadi suami, ataupun cara menghadapi pria ketika menjadi istri. Orang tua hanya memberi batasan yang kurang jelas, seperti “jangan main sama cewek/ cowok". Rata-rata pria atau wanita mendapat gambaran tentang pernikahan justru dari luar keluarga, sangat sedikit yang mendapat pendidikan tentang pernikahan dari keluarga itu sendiri. Satria sendiri mendapat gambaran tentang pernikahan dari orang tua pada waktu SMP hanya dengan kata-kata "pernikahan itu gini, gak selamanya manis", namun orang tuanya hanya menjelaskan sebatas itu saja tanpa memberikan alasan yang tepat, seperti misal pertanyaan kenapa tidak boleh pacaran, kenapa takut hamil, kenapa bisa hamil, dll. Mereka tidak bisa menjelaskan karena memang tidak memiliki pengetahuan tentang pendidikan pernikahan juga. Orang tua kebanyakan hanya 
menjelaskan persiapan pernikahan dari segi materi, namun bukan dari segi mental. Orang tua tidak memberikan pemahaman tentang standar kemapanan, sehingga pria dan wanita memiliki standar kemapanan yang berbeda. Apalagi saat ini umum terjadi perubahan pola asuh dimana orang tua terpaut jarak denan anaknya sehingga hanya mengandalkan komunikasi yang termediasi oleh teknologi informasi yang memiliki banyak keterbatasan (Chen, 2019). Wanita di Indonesia memiliki pemahaman bahwa standar mapan adalah secara finansial, padahal seharusnya mapan haruslah secara emosi, pengetahuan, dan finansial. Ratarata klien yang baru menikah tidak memiliki pengetahuan tentang kemapanan tersebut, padahal saat ini banyak seminar tentang pernikahan, namun mereka kebanyakan tidak tertarik karena menurut mereka menikah itu adalah hal yang mudah, yang penting sudah cinta.

\section{SIMPULAN}

Banyak konflik yang terjadi dalam rumah tangga disebabkan oleh ketidak mampuan pasangan untuk melakukan komunikasi secara efektif. Faktor perbedaan gender menjadi salah satu masalah komunikasi karena pria mempunyai cara berbicara maupun mendengar yang berbeda dengan wanita. Kesulitan berkomunikasi secara tepat menyebabkan proses penyampaian perasaan tidak terjadi secara efektif, banyak kegagalan encoding-decoding pesan. Faktor lain yang mempengaruhi adalah pola komunikasi keluarga pada saat kecil, hal itu sangat mempunyai dampak terhadap pasangan ketika sudah dewasa. Pendidikan tentang pernikahan yang didapat ketika masih kecil juga membuat perilaku pasangan ketika dewasa berubah. Salah satu cara untuk mengkomunikasikan apa yang diinginkan secara tepat adalah melalui proses coaching, karena dalam proses coaching ini, klien akan dilatih untuk menemukan diri sendiri dari ceritanya sendiri dan cara mereka menghadapi konflik dan mengembalikan solusi terhadap konflik itu keklien sendiri dari hasil coaching.

\section{DAFTAR PUSTAKA}

Bodenmann, G., Ledermann, T., \& Bradbury, T. N. (2007). Stress, sex, and satisfaction in marriage, $14,551-569$.

Chen, H. (2019). Toward Traditional or Atypical Parenting: Mediated Communication in Chinese Transnational Families. International Journal of Communication, 13, 1805-1824.

Cook, E. C., \& Fletcher, A. C. (2012). (2012). A process model of parenting and adolescents' friendship competence. Social Development, 21(3), 461-481.

Daryanto. (2010). Ilmu Komunikasi. Bandung: PT.Sarana tutorial nurani sejahtera.

De Vito, J. A. (2004). The Interpersonal Communication Book (10th ed.). New York: Pearson.

English, T., John, O. P., Srivastava, S., \& Gross, J. J. (2012). Emotion regulation and peer-rated social functioning: A 4-year longitudinal study. Journal of Research in Personality, 46, 780-784.

English, T., \& John, O. P. (2013). Understanding the social effects of emotion regulation: The mediating role of authenticity for individual differences in suppression. Emotion, 13, 314-329.

Fatchan, A. (2013). Metode Penelitian Kualitatif: 10 Langkah Penelitian Kualitatif Pendekatan Konstruksi dan Fenomenologi. Malang: UM Press.

Folsom, J. K. (1958). Communication in Marriage and Marriage Counseling. Marriage and Family Living, 20(2), 113-116.

Hall, S. S., \& Adams, R. A. (2011). Newlyweds' unexpected adjustments to marriage. Family and Consumer Sciences Research Journal, 39, 375-387.

Harper, R. A. (1958). Communication Problems in Marriage and Counseling. Marriage and Family Living, 20(2), 107-112.

James, Z. R., \& Mazer, J. P. (2012). Personality, 
communication apprehension, and Facebook: A study of well-being and relational closeness outcomes. International Journal of Arts \& Sciences, 5(6), 125-146.

Karel, R. S., Sondakh, M., \& Pasoreh, Y. (2014). Komunikasi Antar Pribadi Pada Pasangan Suami Istri Beda Negara (Studi Pada Beberapa Keluarga Di Kota Manado). Acta Diurna, 3(4).

Kuswarno, E. (2009). Fenomenologi: Konsepsi, Pedoman, dan Contoh Penelitiannya. bandung: Widya Padjadjaran.

Ledermann, L., G., B., Rudaz, M., \& Bradbury, T. N. (2010). Stress, Communication, and Marital Quality in Couples. Family Relations, 59(2), 195-206.

Litiloly, F., \& Swastiningsih, N. (2014). Manajemen Stres Pada Istri Yang Mengalami Long Distance Marriage. Jurnal Fakultas Psikologi, 2(2).

Morreale, S. P. (Ed.). (2011). "Competence and Incompetence communication." 21 st century communication: AReference Handbook.Ed. Thousand Oaks,CA: Sage Reference online.

Odenweller, K., Booth-Butterfield, M., \& Weber, K. (2014). Investigating helicopter parenting, family environments, and relational outcomes for millennials. Communication Studies, 65(4), 407425. Retrieved from file:///C:/Users/ Irawan/Downloads/11226-44998-1PB.pdf

Oswell, D. (2006). Culture and Society. Sage Publications Ltd (1st ed., Vol. 1). London: Sage Publications Ltd. https:// doi.org/10.1177/02632760022051310

Reckzek, C., Liu, H., \& Umberson, D. (2010). Just the Two of Us? How Parents Influence Adult Children's Marital Quality. Journal of Marriage and Family, 72(5), 1205-1219.

Rini, Y. S. (2014). Komunikasi OrangtuaAnak dalam Pengambilan Keputusan
Pendidikan. Interaksi, 3(2), 112-122.

Ritchie, L. D., \& Fitzpatric, M. A. (1990).

Family Communication Pattern: Measuring Intrapersonal Perception of Interpersonal Relationships. Communication Research, 17(4), 523544.

Saguni, F. (2014). Pemberian Stereotype Gender. Musawa, 6(2), 195-224. Retrieved from https://media.neliti. com/media/publications/138333-IDpemberian-stereotype-gender.pdf

Shun, Y., \& Wilkinson, J. S. (2020). Parenting Style, Personality Traits, and Interpersonal Relationships: A Model of Prediction of Internet Addiction. International Journal of Communication, 14, 2163-2185. Retrieved from file://C:/Users/Irawan/ Downloads/11226-44998-1-PB.pdf

Suroyya, D., Wisadirana, D., \& Suryadi. (2014). Pengaruh Sikap Etnosentris Interpersonal Communication Competence Dan Gaya Komunikasi Terhadap Efektivitas Komunikasi Etnis Tionghoa Kepada Etnis Jawa di Kecamatan Ambulu Kabupaten Jember. Wacana, 3 .

Tannen, D. (1990). You Just don't Understand: Women and Men in Conversation. New York: Ballantine Books.

Vangelisti. (2004). Handbook of Family Communication. New Jersey: Lawrence Erlbaum Associates.

Velotti, P., Balzarotti, S., Tagliabue, S., English, T., Zavattini, G. C., \& Gross, J. J. (2016). Emotional suppression in early marriage. Journal of Social and Personal Relationships, 33(3), 277-302. https:// doi.org/10.1177/0265407515574466

Wardyaningrum, D. (2013). Komunikasi Untuk Penyelesaian Konflik Dalam Keluarga : Orientasi Percakapan Dan Orientasi Kepatuhan. Jurnal Al-Azhar Indonesia Seri Pranata Sosial, 2(1). 